\title{
脳低温療法時の肺酸素化能に及ぼす 口鼻腔内ケアの効果
}

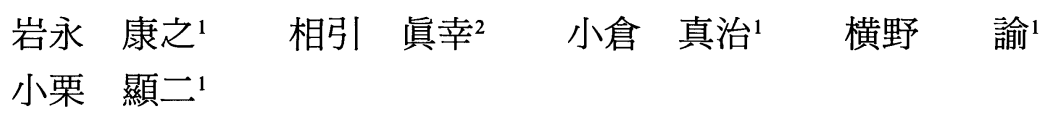

\begin{abstract}
要旨 当病院集中治療部に入室し, 脳低温療法を受けた 16 例を対象に, 口鼻腔内ケアが脳低温療 法時の肺酸素化能に及ぼす影響を retrospective に検討した。口鼻腔内ケアを定期的には施行しな かった非施行群 (年齢 15-85 歳, 男性 1 例, 女性 6 例, 来院時 GCS 3-10 点) 7 例, 同ケアを 1 日 3 回以上施行した施行群（年齢 4-80 歳, 男性 4 例, 女性 5 例, 来院時 GCS 3-11 点） 9 例とに分 け, (1 ) P/F ratio,（2 ） CRP, WBC，（3）咽頭・喀痰培養，（4）胸部 X 線写真について, 両群間で検討した。データは平均値士標準誤差で示した。結果：(1) P/F ratio が 250 以下と肺 酸素化能が悪化した回数の全測定回数に対する割合は, 施行群が $8.0 \pm 3.4 \%$, 非施行群が $36.6 \pm$ $10.1 \%$ (平均值士標準誤差) であり, 施行群が非施行群に対して有意に $(\mathrm{p}<0.05)$ 低率であった。 ( 2 ) CRP は療法前は両群で差はなかったが, 低体温中に施行群が $4.3 \pm 0.8$, 非施行群が $8.5 \pm 0.9$ $\mathrm{mg} / \mathrm{dl}$ と, 施行群が非施行群に比して有意に $(\mathrm{p}<0.01)$ 低值を示した。WBC は両群間に有意差 を認めなかった。( 3 ) 細菌検査では, 両群でまったく同一の抗生剤の使用下にもかかわらず, 施 行群ではグラム陽性菌および陰性菌の両方が (陽性菌 2 種・陰性菌 11 種), 非施行群ではグラム 陰性菌 (5 種) のみが検出された。さらに非施行群では経過中に真菌が気管内採痰より検出された が, 施行群ではまったく検出されなかった。（4)脳低温療法中, 非施行群に(非施行群vs 施行群： $181 \pm 10.4 \%$ vs $0 \%)$ 胸部 X 線写真上明らかな硬化像を高率に認めた。以上の結果より, 脳低温療 法中 1 日 3 回以上の口鼻腔内ケアが, 肺合併症の予防に有効であった。

(日救急医会誌 $1999 ； 10 ： 407-14$ )

キーワード：脳低温療法, 口鼻腔内ケア, 肺酸素化能, 脈血酸素分圧/吸入気酸素分画比
\end{abstract}

\section{はじめに}

近年, 重症脳障害に対して脳低温療法が広く行わ れ，比較的安全に施行されるようになった ${ }^{1,2)}$ が，管 理次第では生命や予後にかかわる合併症が起こる可 能性もある。なかでも同療法中の呼吸器感染症が問 題となることが多い3)。実際, われわれのこれまで経 験した脳低温療法施行例 60 例中 2 例は, 呼吸器感染

\footnotetext{
Effects of oro-nasal care on pulmonary oxygenation during moderate hypothermia therapy for brain-injured patients 1 香川医科大学麻酔・救急医学講座 2 同大学附属病院集中 治療

著者連絡先： T 673-0848 兵庫県明石市鷹匠町 1-33 明石市立市民病院麻酔科

原稿受理日：1998 年 9 月 21 日 (98-056)
}

症で失っている。一方, 通常の肺炎の発生に口腔内 細菌の関与が知られ，それを口鼻腔内ケアで予防で きるという報告が散見される ${ }^{4-7)}$ 。われわれは，同ケ アが脳低温療法時の呼吸器感染症予防にも有効と考 え, 当施設で行っている口鼻腔内ケアが, 脳低温療 法時の肺酸素化能に及ぼす影響を retrospective に 検討したので報告する。

\section{対象と方法}

\section{1. 対 象}

1995 年 3 月から 1997 年 6 月までの間に当院集中 治療部に入室し脳低温療法を受けた 20 例のうち, 来 院時より誤嬩や肺炎が明らかであった症例を除く 16 例を対象とした。内訳は，口鼻腔内ケアを定期的 
Table 1. Patient characteristics.

Group A

\begin{tabular}{|c|c|c|c|c|c|c|}
\hline $\begin{array}{l}\text { Case } \\
\text { No. }\end{array}$ & $\begin{array}{l}\text { Daily frequency } \\
\text { of care }\end{array}$ & Age & Sex & GCS & $\begin{array}{l}\text { Duration of } \\
\text { hypothermia } \\
\text { (days) }\end{array}$ & Type of injury \\
\hline 1 & NR & 64 & $\mathrm{~F}$ & 3 & 7 & head injury \\
\hline 2 & NR & 57 & $\mathrm{~F}$ & 10 & 9 & cerebral infarction \\
\hline 3 & NR & 15 & $\mathrm{~F}$ & 4 & 16 & head injury \\
\hline 4 & NR & 18 & M & 7 & 5 & head injury \\
\hline 5 & NR & 65 & $\mathrm{~F}$ & 5 & 9 & intracerebral hemorrhage \\
\hline 6 & NR & 58 & $\mathrm{~F}$ & 5 & 15 & $\mathrm{SAH}$ \\
\hline 7 & NR & 85 & $\mathrm{~F}$ & 4 & 12 & intracerebral hemorrhage \\
\hline \multicolumn{7}{|c|}{ Group B } \\
\hline $\begin{array}{l}\text { Case } \\
\text { No. }\end{array}$ & $\begin{array}{c}\text { Daily frequency } \\
\text { of care }\end{array}$ & Age & Sex & GCS & $\begin{array}{c}\text { Duration of } \\
\text { hypothermia } \\
\text { (days) }\end{array}$ & Type of injury \\
\hline 1 & 3 times & 4 & M & 6 & 11 & head injury \\
\hline 2 & 3 times & 72 & M & 3 & 13 & cerebral infarction \\
\hline 3 & 3 times & 80 & $\mathrm{~F}$ & 11 & 10 & $\mathrm{SAH}$ \\
\hline 4 & 3 times & 71 & $\mathrm{~F}$ & 3 & 8 & SAH \\
\hline 5 & 3 times & 69 & $\mathrm{~F}$ & 4 & 14 & SAH \\
\hline 6 & 3 times & 54 & M & 4 & 12 & brain-stem hemorrhage \\
\hline 7 & 3 times & 72 & $\mathrm{~F}$ & 3 & 11 & $\mathrm{SAH}$ \\
\hline 8 & 3 times & 50 & $\mathrm{~F}$ & 6 & 14 & SAH \\
\hline 9 & 3 times & 18 & M & 3 & 10 & head injury \\
\hline
\end{tabular}

Group A: Patients received no regular mouth care.

Group B : Patients were treated with regular mouth care more than three times a day. $\mathrm{NR}=$ not regular $; \mathrm{GCS}=$ Glasgow coma scale on admission $; \mathrm{SAH}=$ subarachnoid hemorrhage

には施行しなかった群 (以下非施行群) 7 例，同ケア を 1 日 3 回以上施行した群 (以下施行群) 9 例とに分 けた。なお，施行群のうち 4 例は 1 日 3 回，5例は 1 日 6 回行った。非施行群は, 年齢 15 歳から 85 歳, 男性 1 名, 女性 6 名であり, 来院時の Glasgow coma scale (以下 GCS) は 3 点から 10 点であった。一方, 施行群は年齢が 4 歳から 80 歳, 男性 4 名, 女性 5 名 であり, 来院時 GCS は 3 点から 11 点であった (Table 1)。脳低温療法は, 原則的に来院時 GCS が 8 点以下の症例に行われたが，各群中の 1 名が GCS 8 点以上であったが，各々手術中の脳浮腫が著明であ つたため例外的に脳低温療法を施行した。両群間に おいて年齢，来院時 GCS，脳低温療法施行期間，施 行中の水分バランス, 使用抗生物質の種類, 量, 療 法開始時の $\mathrm{PaO}_{2} / \mathrm{F}_{\mathrm{I}} \mathrm{O}_{2}$ (以下 $\mathrm{P} / \mathrm{F}$ ratio), $\mathrm{CRP}$ に有
意差は認められなかった。

\section{2. 当施設での脳低温療法の方法 ${ }^{11}$}

ブランケット（RK2000, Baxter；Valencia, USA） による表面冷却にて導入維持し，体温（鼓膜温およ び内頸静脈温）を $32-33^{\circ} \mathrm{C}$ に調節した。低体温中お よび復温中は筋弛緩剤（臭化ベクロニウム 2-3 mg/ $\mathrm{hr}$ ), 鎮静剤 (ミダゾラム $3-5 \mu \mathrm{g} / \mathrm{kg} / \mathrm{min}$ ), 鎮痛剤(塩 酸ブプレノルフィン 0.6-0.8 mg/day)をそれぞれ投 与した。また人工呼吸下に管理を行い, $\mathrm{PaCO}_{2}$ を 30$33 \mathrm{mmHg}$ 程度に調節した $(\alpha-$ stat 管理：血液ガスデ ータは体温補正していない)。復温は 1 日 $1^{\circ} \mathrm{C}$ を目 標に緩徐に行った。 


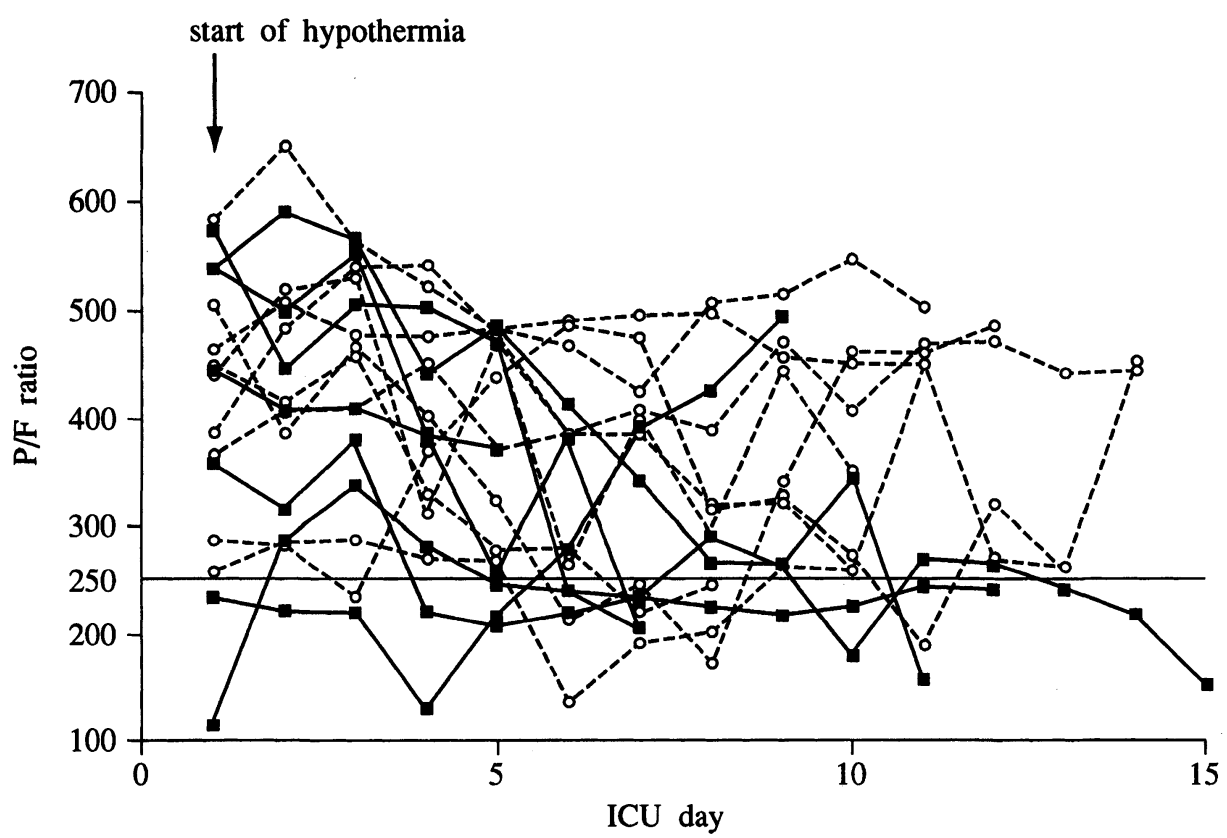

Fig. 1. Changes in $\mathrm{PaO}_{2} / \mathrm{F}_{\mathrm{I}} \mathrm{O}_{2}$ ratio in each group during ICU stay. The arrow indicates the start of hypothermia therapy. Note that after initiation of the therapy, the $\mathrm{P} / \mathrm{F}$ ratio gradually decreased in group A, but not in group B. Closed squares show data of patients who did not undergo regular care (group A), open circles those of patients who received regular oro-nasal care (group B).

\section{3. 口鼻腔内ケアの施行法}

まずケア前に口腔, 鼻腔, 気管内の吸引を行い, 気管チューブのカフ圧を上げる（1 cc エア追加注 入)。次に $250 \mathrm{ml}$ の水で口鼻腔中を吸引しつつ洗浄 し，ポピドンヨード消毒原液（イソジン液）を含ま せた歯ブラシを用いて, 歯, 歯肉, 舌部をブラッシ ング。この際出血傾向のある患者には，ブラッシン グの代りに綿棒によるマッサージを行った。再び $250 \mathrm{ml}$ の水で洗浄し, 綿棒にて同消毒液を咽頭粘 膜, 歯肉, 舌, 鼻腔に塗布し, 気管内を吸引後, 力 フ圧をもとに戻す。最後に呼吸音を確認して終了し $た^{3)}$ 。

\section{4. 検討項目}

( 1 ) $\mathrm{PaO}_{2} / \mathrm{F}_{\mathrm{I}} \mathrm{O}_{2}$ (以下 $\mathrm{P} / \mathrm{F}$ ratio: 肺酸素化能の 一指標) が 250 以下となった回数の全測定回 数に対する割合，

（2）各療法時点での CRP, WBC の測定值,

（3）咽頭・気管内採痗の細菌検査の結果,

（4）各症例における胸部 X 線写真上での con-

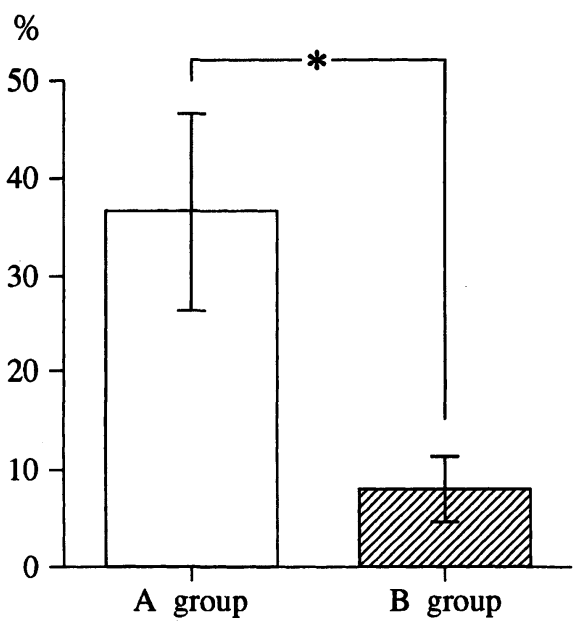

Fig. 2. Comparisons of the rate of $\mathrm{PaO}_{2} / \mathrm{F}_{\mathrm{I}} \mathrm{O}_{2}$ ratio less than 250 in total samples between groups $\mathrm{A}(\mathrm{N}=7)$ and B $(\mathrm{N}=9) \quad($ mean $\pm \mathrm{SE})$. An astrerisk shows statistical difference (MannWhitney $\mathrm{U}$-test, $\mathrm{p}<0.05$ ). An open bar shows mean value of the group $A$, a hatched bar that of group B.

solidation の出現率

の以上 4 点を検討項目とし，両群間で比較検討し た。データは平均值士標準誤差で示し, 統計学的検 


\section{CRP}
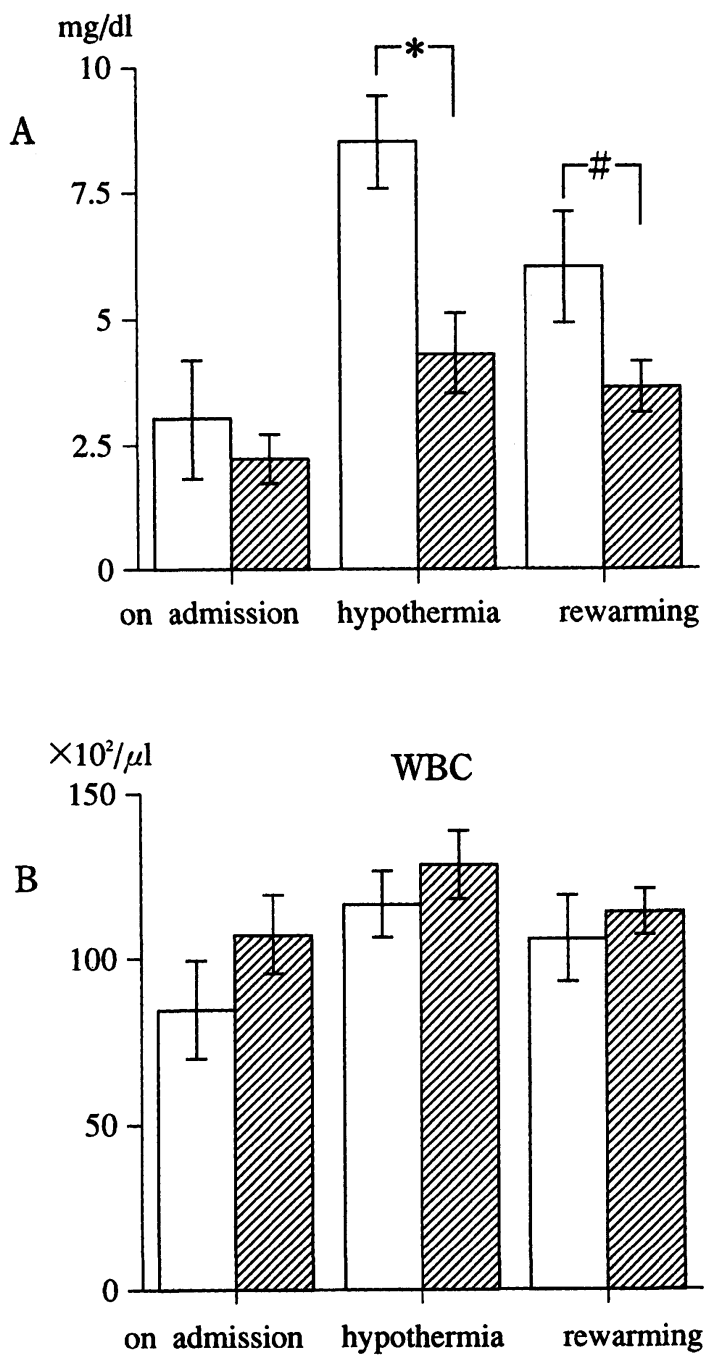

Fig. 3. A : Comparisons in plasma CRP levels between groups $\mathrm{A}(\mathrm{N}=7)$ and $\mathrm{B}(\mathrm{N}=9)$ (mean \pm $\mathrm{SE})$. Astrerisk and sharp mark show statistical differences between the groups (unpaired student t-test, $\left.{ }^{*} \mathrm{p}<0.01,{ }^{\#} \mathrm{p}<0.05\right)$. Note that CRP levels in group A were significantly higher than those of group B in the hypothermia as well as rewarming period.

$\mathrm{B}$ : Comparison of WBC between groups A $(\mathrm{N}=7)$ and $\mathrm{B}(\mathrm{N}=9)($ mean $\pm \mathrm{SE})$. No statistical differences were found between the two groups.

定に Student $\mathrm{t}$-test，または Mann-Whitney U-test を用いた。（1）で用いた指標の定義は，1 日数回行 う動脈血液ガス測定中，午前 7 時の採血時の值を採 用し，その中で $\mathrm{P} / \mathrm{F}$ ratio が 250 以下となった回数 を，脳低温療法日数で除したものである。なお，両 群の $\mathrm{P} / \mathrm{F}$ ratio のサンプル数は非施行群 100 (14士2/

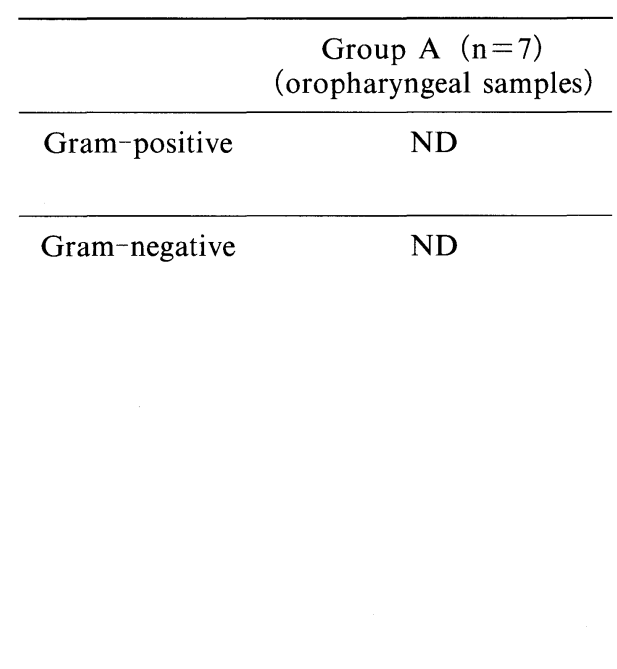

Fungus

Candida tropicalis (1)

例）回, 施行群 $135(14 \pm 2 /$ 例 $)$ 回と有意差を認めな かった。

\section{結 果}

（1）Fig. 1 に示すように低温療法中の全症例の $\mathrm{P} / \mathrm{F}$ ratio の経過をみると, 施行群と比較して非施行 群では，日を追うごとに低下傾向にある。Fig. 2 に示 すように, P/F ratio が 250 以下となった回数の全測 定回数に対する割合は, 施行群が $8.0 \pm 3.4 \%$, 非施行 群が 36.6土10.1\%であり, 施行群が非施行群に対し て有意に（p<0.05）低率であった。

（2）CRP は入室時は両群間において有意差はな かったが, 低体温中は施行群が $4.3 \pm 0.8 \mathrm{mg} / \mathrm{dl}$, 非 施行群が $0.5 \pm 0.9 \mathrm{mg} / \mathrm{dl}(\mathrm{p}<0.01)$ ，また復温中は 施行群が $3.6 \pm 0.5 \mathrm{mg} / \mathrm{dl}$, 非施行群が $6.0 \pm 1.1$ $\mathrm{mg} / \mathrm{dl}(\mathrm{p}<0.05)$ と，それぞれ施行群が非施行群に 対して有意に低值を示した。一方 WBC の変化は, 入 室時・低体温中・復温中のいずれにおいても両群間 に有意差を認めなかった（Fig. 3）。 
Table 2. Bacterial profile in oropharyngeal and tracheal samples in both groups.

\begin{tabular}{|c|c|c|}
\hline $\begin{array}{l}\text { Group A }(\mathrm{n}=7) \\
\text { (tracheal samples) }\end{array}$ & $\begin{array}{c}\text { Group B }(n=9) \\
\text { (oropharyngeal samples) }\end{array}$ & $\begin{array}{l}\text { Group C }(\mathrm{n}=9) \\
\text { (tracheal samples) }\end{array}$ \\
\hline & $\begin{array}{l}\text { Staphylococcus aureus (2) } \\
\text { Staphylococcus epidermidis (1) }\end{array}$ & $\begin{array}{c}\text { Staphylococcus aureus (2) } \\
\text { Staphylococcus epidermidis (1) }\end{array}$ \\
\hline $\begin{array}{c}\text { *Stenotrophomonas maltophilia } \\
\text { Pseudomonas aeruginosa }\end{array}$ & $\begin{array}{c}\text { Stenotrophomonas maltophilia } \\
\text { Pseudomonas aerugincsa }\end{array}$ & $\begin{array}{c}\text { Stenotrophomonas maltophilia (3) } \\
\text { Pseudomonas aeruginosa (2) } \\
{ }^{* *} \text { Burkholdeia cepacia }\end{array}$ \\
\hline Klebsiella pneumoniae (1) & $\begin{array}{c}\text { Klebsiella pneumoniae } \\
\text { Klebsiella oxytoca } \\
\text { Enterobacter cloacae } \\
\text { Enterobacter aerogenes }\end{array}$ & $\begin{array}{c}\text { Klebsiella pneumoniae } \\
\text { Klebsiella oxytoca } \\
\text { Enterobacter cloacae } \\
\text { Enterobacter aerogenes }\end{array}$ \\
\hline Escherichia coli (1) & $\begin{array}{c}\text { Enterococcus faecalis (1) } \\
\text { Acinetobactor calcoaceticus (2) }\end{array}$ & Acinetobactor calcoaceticus (2) \\
\hline Serratia marcescens (1) & $\begin{array}{c}\text { Serratia marcescens (1) } \\
\text { Aeromonas hydrophila (1) }\end{array}$ & \\
\hline $\begin{array}{l}\text { Candida tropicalis }(1) \\
\text { Candida glablata } \\
\text { Candida spp }\end{array}$ & & \\
\hline
\end{tabular}

Group $\mathrm{A}=$ patients received regular mouth care ; Group $\mathrm{B}=$ patients received regular mouth care more than three times a day $; \mathrm{ND}=$ not determined

Numbers in parentheses show numbers of patients who underwent bacteriological examinations;

${ }^{*}$ xanthomonas maltophilia (previous) ${ }^{* *}$ pseudomonas cepacia (previous)

（３）両群で行われたすべての細菌検査を集計し た。その結果，咽頭ぬぐい液および気管内採痰の細 菌検査において，施行群では咽頭より検出された菌 のほとんどが喀痰からも検出された。施行群ではグ ラム陽性菌・陰性菌の両方が（陽性菌 2 種・陰性菌 11 種) 検出されたのに対し, 非施行群では, グラム 陰性菌 (5 種) のみが検出された (Table 2)。さらに, 非施行群で気管内採㾳より真菌が検出されたのに対 し，施行群では真菌はまったく検出されなかった。

（4）各群において, 各症例が胸部写真上硬化像を 認めた低温療法中の頻度は $18.1 \pm 10.4 \%$ vs 0\%（非 施行群 vs 施行群) と非施行群が施行群に比し有意に 高率であった（Fig. 4)。

\section{考察}

1960 年に Rosomoff によって，脳損傷における低 体温療法の脳保護作用が報告された ${ }^{8)}$ が， $30^{\circ} \mathrm{C}$ 以下 の低体温は不整脈や出血傾向など危険な合併症を伴 い，臨床的に施行困難であった。しかし，1987 年の

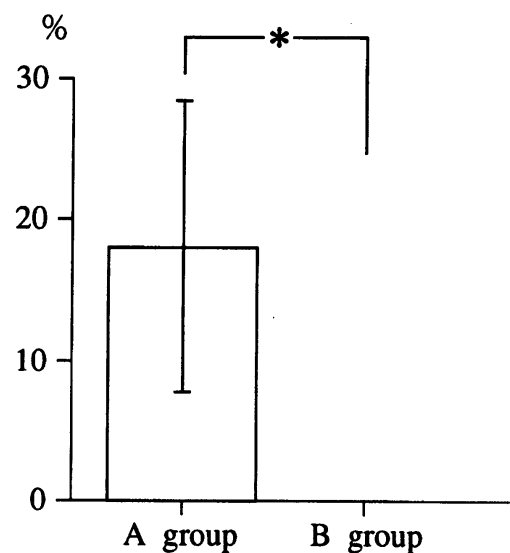

Fig. 4. Comparison of the rate of developing consolidation on chest $\mathrm{X}$-ray film between groups $\mathrm{A}(\mathrm{N}=7)$ and $\mathrm{B}(\mathrm{N}=9)$ (mean \pm $\mathrm{SE})$. An astrerisk shows statistical difference (Mann-Whitney $\mathrm{U}$-test, $\mathrm{p}<0.05$ ).
Busto の報告9) 以来, $32-33^{\circ} \mathrm{C}$ 程度の軽度低体温療法 でも脳保護作用があるとの報告が相次ぎ，近年の集 中治療医学の進歩とも相まって, 低体温療法が臨床 的に行われるようになってきた。しかし，軽度低体 
温においても白血球の走化性や貪食能は低下すると 考えられ ${ }^{10)}$ ，また鎮静剤, 筋弛緩剂の投与下に長期の 人工呼吸を強いられるため, 肺炎等の呼吸器感染症 の合併が問題となる。

今回の研究では, 低体温療法中, 肺酸素化能の一 指標である $\mathrm{P} / \mathrm{F}$ ratio の全経過と, $\mathrm{P} / \mathrm{F}$ ratio が 250 以下に低下した割合が，口鼻腔内ケア施行群で非施 行群に比し，有意に低率となった。さらに全身の炎 症反応の一指標である CRP が, 低温中に施行群で 有意な低値を示した。このことは口鼻腔内ケアが, 低体温療法中においても肺炎予防に有用であること を示している。これまでに林ら ${ }^{11)}$ の報告では，低体 温療法中側臥位等への体位変換が肺合併症の軽減に 有効との指摘があるが，今回示したような実際の炎 症反応の程度や，肺酸素化能の比較はなされていな い。

今回の検討で明らかなように口鼻腔ケアの施行, 非施行群で, 体位変換の頻度に差がないにもかかわ らず，口鼻腔ケアの施行程度の差で，CRP および肺 酸素化能に差が生じた。このことは, 脳低温療法中 の肺合併症の軽減には，口鼻腔内ケアが，体位変換 よりさらに有効である可能性を示唆している。

今回, 白血球数の変化は低温中, 復温中のいずれ においても両群間に差を認めなかったが, CRP につ いては両群間で低温中および復温中に有意差を認め た。この機序として, 白血球数については低体温療 法自体による増加反応性の低下が想定される ${ }^{10)} 。-~$ 方 CRP は, サイトカイン, とくに IL-6により肝で 誘導されることが知られており ${ }^{12)}, 32-33^{\circ} \mathrm{C}$ 程度の 低体温療法中，その反応性が保たれていたため，今 回のような結果となった可能性がある。最近われわ れは, 頭部損傷例の動脈血中の IL-6 を検討し, 常温 管理では IL-6 が低下しないものの，低温管理する と IL-6 が早期に低下することや，復温時に IL-6 が 再上昇するものは予後不良であることを報告してい $3^{13,14)}$ 。さらにこの動脈血中の IL-6 の増加は, 脳で 産生された IL-6 が内頸静脈を介して全身に漏れ出 た可能性も指摘している。その脳内から産生された
サイトカインが，頭部外傷における血中 CRP や白 血球数の増加に関与しているとの報告もある ${ }^{15)}$ 。今 回, 両群の脳低体温中の CRP の差に関しては, 頭部 外傷やクモ膜下出血等, 脳内病変の差異による, 脳 内で産生されるサイトカイン量の差(未発表データ) に起因している可能性も否定できない。いずれにし ても, 今回の CRP と白血球数の反応差については, 今回の結果からは明確な説明は困難である。今後, 低体温療法中における白血球産生と CRP の肝臓で の産生の反応差について検討が必要である。

人工呼吸中の silent regurgitation については以前 より報告され，その予防法についての報告も散見さ れる。この silent regurgitation は, 主に口腔内細菌 が気管内チューブの外壁を伝って迷入することによ り発生すると考えられており，その意味でも，気管 内挿管患者における口鼻腔内ケアの重要性が理解で きる。実際, 今回の検討でも咽頭拭い液と気管内採 痰との細菌検査の結果でも, 細菌種がほとんど一致 していた。

非施行群では，気管内採痰の培養と咽頭培養が一 対では行われなかったが，おそらく同群においても 咽頭細菌と同一の菌が，気管内にも見出されたもの と思われる。今回, 両群でまったく同種の抗生剤が 使用されたにもかかわらず，口鼻腔内ケアを定期的 に行わなかった群において, 各例でほぼ単一菌種(グ ラム陰性菌）が検出された。これは抗生剤投与によ る口腔内常在菌（Streptococcus milleri や Peptostreptococcus 属等) の除菌後の菌交代現象といえる ${ }^{16)} 。$ さらに, ケア施行群では真菌がまったく検出されな かったにもかかわらず，ケア非施行群では真菌が咽 頭および気管内採痰より検出された。また，両群で 同じ抗生剂投与にもかかわらず，ケア非施行群でグ ラム陰性菌のみが検出されたのに対し，同ケア施行 群においては，気管内および口腔内に複数のグラム 陰性およびグラム陽性菌が検出された。このことは 同ケア施行時に，ケア施行者からの細菌移行を含め た何らかの原因により菌が付着したか，口鼻腔ケア 後一時間程度は, ほとんどの菌量が減少するため(未 
発表デー夕）Staphylococcus aureus やStaphylococcus epidermidis 等のグラム陽性菌が定着し，培養さ れた可能性もある。今回, 検出細菌種が多かったケ ア施行群で，肺酸素化能の悪化が少なかったことや CRP の低值を認めたことは，興味深い知見といえ る。口腔内グラム陽性および陰性細菌の相互作用が なんらかの有益的な効果を示す可能性もあり ${ }^{16)}$, 今 後の検討課題であろう。

\section{結語}

脳低温療法中 1 日 3 回以上の口鼻腔内ケアが, 肺 合併症の予防に有効であった。

謝辞 この研究施行に，臨床現場で協力・支援くだ さった香川医科大学附属病院手術部・集中治療部看護 者の方々に深謝致します。

\section{文献}

1）相引眞幸, 小倉真治, 横野諭, 他：軽度低体温療法と 免疫機構. 新井達潤編. 脳蘇生と低体温療法. 真興交 易医書出版部，東京，1997，p 85-95.

2）浅賀健彦，相引眞幸，小倉真治，他：低体温療法中の 電解質の変化一使用鎮静薬による差一(チアミラール とミダゾラムでの検討)。ICU と CCU 1997；21： 967-73.

3）小倉真治, 相引眞幸, 横野諭：軽度低体温療法の合併 症。新井達潤編。脑蘇生と低体温療法。真興交易医書 出版部，東京，1997， p 107-20.

4）小倉真治, 相引眞幸：低体温療法の導入. 救急医 $1998 ; 22: 466-7$.

5）西岡信子, 安田壽賀子, 相引眞幸, 他：看護業務！呼 吸器系。一口腔内ケア, 気管内吸引と洗浄, 体位変換 そして手指消毒のポイントー，エマージェンシーナー
シング 1997 ; 夏季増刊：108-13.

6）都温彦：口腔ケアの意義一特に嚥下性肺炎の予防を中 心に一。 日本歯科評論 $1996 ; 649 ： 175-83$.

7）米山武義：誤嚥と嶼下性肺炎口腔ケアと誤嚥性肺炎. Geriatric Medicine 1997；35:167-71.

8) Rosomoff HL, Shulman K, Raynor R, et al : Experimental brain injury and delayed hypothermia. Surg Gynecol Obstet $1960 ; 110: 27-32$.

9) Busto R, Dietrich WD, Globus MY, et al: Small deferences in intraischemic brain temperature critically determine the extent of ischemic neuronal injury. $\mathbf{J}$ Cereb Blood Flow Metab 1987; 7 : 729-38.

10) Biggar WD, Bohn DJ, Kent G, et al : Neutrophil migration In vitro and in vivo during hypothermia. Inferction and Immunity $1984 ; 46: 857-9$.

11）林成之，木下浩作，雅楽川聡，他：脳低体温療法の成 否を決定する技術的な問題点と対策. 集中治療 $1997 ; 9: 675-86$.

12) Ohzato H, Yoshizaki K, Nishimoto N, et al : Interleukin-6 as a new indicator of inflamatory status : detection of serum levers of interleukin 6 and C-reactive protein after surgery. Surgery $1992 ; 111: 201-9$.

13) Aibiki M, Maekawa S, Ogura S, et al : Mild hypothermia suppresses plasma interleukin-6 elevation in patients with traumatic brain injury. In The Immune Consequences of Trauma, Shock and Sepsis, Mechanisms and Therapeutic Approaches (Faist eds). Mouduzz, Bolona, 1997, p 139-42.

14) Aibiki M, Maekawa $S$, Ogura $S$, et al: Effects of moderate hypothermia on systemic and internal jugular plasma IL-6 levels after traumatic brain injury in humans. J Neurotrauma $1999 ; 16: 225-32$.

15) McClain C, Cohen D, Phillips R, et al: Increased plasma and ventricular fluid Interleukin-6 levels in patients with head injury. J Lab Clin Med 1991; $118: 225-31$.

16）藤森功, 山田俊彦, 菊島一仁, 他：咽頭常在菌の各種 病原菌に対する発育抑制作用。日扁桃研会誌 1993 ; $32: 46-50$ 


\section{ABSTRACT \\ Effects of Oro-nasal Care on Pulmonary Oxygenation \\ During Moderate Hypothermia Therapy for Brain-Injured Patients. \\ Yasuyuki Iwanaga' ${ }^{1}$, Mayuki Aibiki², Shinji Ogura ${ }^{1}$ \\ Satoshi Yokono ${ }^{1}$ and Kenji Ogli ${ }^{1}$ \\ ${ }^{1}$ Department of Anesthesiolosy and Emergency Medicine, Kagawa Medical University \\ ${ }^{2}$ Division of Intensive Care Unit, Kagawa Medical University Hospital}

We have retrospectively studied the effects of oro-nasal care on pulmonary oxygenation during moderate hypothermia therapy in 16 patients with cerebral vascular disease or head trauma. Moderate hypothermia were undergone for 3-16 days. Seven of 16 patients did not receive regular mouth care (group A), and the others were treated with regular mouth care more than three times a day (group $\mathrm{B}$ ). $\mathrm{PaO}_{2} / \mathrm{F}_{\mathrm{I}} \mathrm{O}_{2}$ ratio ( $\mathrm{P} / \mathrm{F}$ ratio), $\mathrm{CRP}, \mathrm{WBC}$ counts and chest $\mathrm{X}$-rays were examined. Oro-nasal or tracheal secretions were cultured for bacteriological examination. In this study, the frequency of $\mathrm{P} / \mathrm{F}$ ratio less than 250 in all samples during the therapy, including rewarming period, was defined as the index for determining pulmonary oxygenation (the decreased frequency). Statictical analysis was done by student $t$-test or Mann-Whitney $U$-test as appropriate. P values less than 0.05 were considered significant. The decreased frequency in group B was significantly lower than that of group A, suggesting group B had superior pulmonary oxygenation to group A. CRP on admission was not different between the groups, but the variable in group B was significantly lower than that of group A in the hypothermic and rewarming period. Changes in WBC counts between the groups were not significantly different. On chest $\mathrm{X}$-ray, the mean rate of development of consolidation was significantly higher at $18.1 \pm 10.4 \%$ in group A than group B (0\%). These data show that oronasal care more than three times a day improves pulmonary oxygenation during hypothermia therapy for braininjured patients.

(JJAAM 1999；10：407-14)

Key Words : moderate hypothermia, aero-nasal care, pulmonary oxygenation, $\mathrm{PaO}_{2} / \mathrm{F}_{\mathrm{l}} \mathrm{O}_{2}$ ratio

Received for publication on September 21, $1998 \quad(98-056)$ 